\title{
KORELASI LAMA OPERASI DENGAN PERUBAHAN KADAR NATRIUM PASCA OPERASI TRANSURETHRAL RESECTION OF THE PROSTATE DI RSUP DR. M. DJAMIL PADANG
}

\author{
Rani Novelty ${ }^{1}$, Zelly Dia Rofinda ${ }^{2}$, Etriyel MYH ${ }^{3}$
}

\begin{abstract}
Abstrak
Transurethral Resection of the Prostate (TURP) pada pasien Benign Prostatic Hyperplasia (BPH) dengan indikasi absolut operasi. menggunakan suatu cairan irigasi. Cairan irigasi tersebut dapat masuk ke sirkulasi yang menimbulkan suatu kondisi intoksikasi air. Kelebihan cairan, yang terserap karena proses operasi TURP, dapat menyebabkan terjadinya hiponatremia akut, kejadian ini disebut sindroma TURP. Terjadinya sindroma TURP memang tergolong jarang, tetapi sindroma TURP memiliki komplikasi yang bahkan dapat menyebabkan kematian. Tujuan penelitian ini adalah menentukan korelasi lama operasi terhadap perubahan kadar natrium pasca operasi TURP di RSUP Dr. M. Djamil Padang. Penelitian ini merupakan studi analitik observasional dengan rancangan potong lintang. Pengambilan sampel dilakukan dengan teknik consecutive sampling. Sampel penelitian berjumlah dua puluh sampel yang diambil dari rekam medis pasien BPH yang melakukan TURP di RSUP Dr. M. Djamil Padang sesuai kriteria inklusi. Analisis data menggunakan uji korelasi Pearson. Hasil penelitian menunjukkan rerata lama operasi TURP adalah 63,25 \pm 18,59 menit dan rerata perubahan kadar natrium adalah 5,0 $\pm 3,4 \mathrm{mEq} / \mathrm{L}$. Uji korelasi Pearson menunjukan terdapatnya hubungan tidak bermakna antara lama operasi terhadap perubahan kadar natrium pasca operasi TURP dengan korelasi sangat lemah positif $(r=0,141, p=0,552)$. Disimpulkan bahwa terdapat adanya korelasi sangat lemah dengan hubungan yang tidak bermakna antara lama operasi terhadap perubahan kadar natrium pasca operasi TURP di RSUP Dr. M. Djamil Padang.
\end{abstract}

Kata kunci: lama operasi, lama TURP, perubahan kadar natrium

\begin{abstract}
Transurethral Resection of the Prostate (TURP) on Benign Prostatic Hyperplasia (BPH) patients with absolute indication for surgery. procedure requires an irrigating fluid. The irrigating fluid would be absorbed into circulation and may cause water intoxication. Fluid overload is caused by large of quantities of irrigating fluid being absorbed during operative, lead to acute hyponatremia known as TURP syndrome. TURP syndrome is rare but its complication is potentially fatal, death may result. The objective of this study was to determine the correlation between the duration of the surgery and the changes in serum concentration of sodium after TURP in Dr. M. Djamil hospital. This study was an analytical observational using cross-sectional study with consecutive sampling technique. There were twenty medical records of patient undergoing TURP procedure that passed inclusion criteria and eligibled for this study. Data were analyzed by using Pearson correlation test. The results showed mean of the duration of the surgery was $63.25 \pm 18.59$ minutes and mean of the concentration of sodium after transurethral resection of the prostate was $5.0 \pm 3.4 \mathrm{mEq} / \mathrm{L}$. There were no statistically significant correlation between the duration of the surgery and the changes in serum concentration of sodium after TURP with very weak positive correlation ( $r=0.141, p=0.552)$. The conclusion is there were very weak correlation with no statistically significant correlation between the duration of the surgery and the changes in serum concentration of sodium after TURP in Dr. M. Djamil hospital.
\end{abstract}

Keywords: duration of surgery, duration of TURP, changes in sodium 
Affiliasi penulis: 1 Prodi Kedokteran Fakultas Kedokteran Universitas Andalas Padang (FK Unand), 2. Bagian Patologi Klinik FK Unand, 3. Bagian Bedah Urologi FK Unand.

Korespondensi: Rani Novelty, Email:

raninovelty6155@gmail.com

\section{PENDAHULUAN}

Transurethral Resection of the Prostate (TURP) merupakan tindakan pembedahan pada pasien Benign Prostatic Hyperplasia (BPH) untuk menyingkirkan jaringan prostat penyebab obstruksi saluran kemih. TURP merupakan standar baku emas untuk tata laksana pasien BPH, dengan volume prostat 30-80 $\mathrm{mL} .{ }^{1,2}$

Benign Prostatic Hyperplasia (BPH) adalah tumor jinak yang sering menyerang pria dan insidensinya meningkat seiring dengan pertambahan usia. ${ }^{3,4}$ Penyakit ini ditandai dengan pertumbuhan nonmalignansi dari kelenjar prostat yang umumnya terjadi pada pria berusia diatas 40 tahun. Berdasarkan beberapa hasil studi autopsi dunia memperkirakan prevalensi BPH sebanyak $20 \%$ pada pria usia 40 tahun, $60 \%$ pada pria usia 60 tahun, dan meningkat sampai $90 \%$ pada pria usia $70-80$ tahun. ${ }^{4}$

Penyakit BPH semakin meningkat dalam waktu beberapa tahun belakangan. ${ }^{5}$ Angka kejadian BPH di RSUP Dr. M. Djamil Padang adalah 3.780 tahun 2006$2011 .^{6}$ Terdapat peningkatan kasus kasus BPH yang dilakukan tindakan TURP di RSUP Dr M. Djamil Padang yang pada tahun 2013 terdapat sebanyak 179 kasus dan meningkat pada tahun 2014 sebanyak 185 kasus. $^{7}$

Terapi untuk BPH dapat berupa observasi sampai tindakan bedah. Pilihan terapi didasari oleh perolehan skor I-PSS (International Prostatic Syndrome Score. ${ }^{3}$ Terapi nonbedah dapat diberikan apabila skor I-PSS sama atau kurang dari 15 dan terapi bedah dapat diberikan apabila skor I-PSS lebih dari $25 .{ }^{8}$ Terapi nonbedah berupa watchfull waiting dan medikamentosa sedangkan untuk terapi bedah berupa Prostatektomi terbuka, Transurethral Incision Prostat (TUIP), dan Transurethral Resection of the Prostate (TURP). ${ }^{3,4}$

Transurethral Resection of the Prostate merupakan prosedur baku untuk terapi bedah $\mathrm{BPH}^{3,6}$ TURP memiliki kelebihan kejadian trauma yang lebih sedikit dan masa pemulihan yang lebih cepat. ${ }^{3}$ TURP dilakukan dengan menggunakan cairan irigasi agar daerah reseksi tetap terlihat dan tidak tertutup darah. Cairan yang digunakan bersifat non-ionic, cairan yang tidak menghantarkan listrik, bertujuan agar tidak terjadi hantaran listrik selama operasi. Contohnya: air steril, glisin, sorbitol/manitol. ${ }^{9,10}$

Cairan yang yang sering dipakai dan harganya cukup murah adalah air steril (aquades). ${ }^{9}$ Air steril memang memiliki syarat-syarat sebagai cairan ideal untuk irigasi, tetapi air steril memiliki kekurangan yaitu bersifat hipotonik. ${ }^{11}$ Sifatnya yang hipotonik menyebabkan cairan dapat masuk ke sirkulasi sistemik melalui pembuluh vena prostat yang terbuka saat operasi. Kelebihan cairan hipotonik dalam sirkulasi sitemik dapat menyebabkan hiponatremia relatif atau gejala intoksikasi air yang dikenal dengan sindroma TURP. $^{9}$

Sindroma TURP adalah salah satu komplikasi tersering dan paling ditakuti. Insiden sindroma TURP meningkat $20 \%$ dengan tingkat kematian yang signifikan. ${ }^{11}$ Angka mortalitas sindroma TURP adalah sebesar $0,99 \% .^{9}$ Beberapa penelitian dalam kurun waktu 20 tahun belakangan menunjukan bahwa insiden sindroma TURP ringan sampai sedang antara 0,5\% sampai $8 \%$ dengan laporan kematian 0,2\% sampai $0,8 \%$. Sedangkan untuk sindroma TURP berat memiliki mortalitas $25 \%$ walaupun jarang terjadi. ${ }^{12}$

Gejala sindroma TURP dapat terjadi pada 15 menit pertama sejak dimulai operasi sampai 24 jam pasca operasi. ${ }^{12}$ Sindroma TURP dapat dikenali dengan gejala pasien yang mulai gelisah, kesadaran somnolen, tekanan darah meningkat, dan bradikardi. Jika tidak segera diatasi, pasien akan mengalami edema otak yang akhirnya akan jatuh dalam koma dan kematian. $^{9}$

Pengurangan resiko timbulnya sindroma TURP, sebaiknya operasi dilakukan tidak lebih dari 1 jam. Cairan lain yang sering digunakan yaitu glisin dapat mengurangi resiko hiponatremia pada TURP, tetapi harganya cukup mahal sehingga beberapa klinik urologi di Indonesia lebih memilih aquades sebagai cairan irigasi. ${ }^{9}$ Tentang cairan mana yang lebih aman dipakai sebagai cairan irigasi TURP sebenarnya masih menjadi perdebatan. ${ }^{13}$

Natrium merupakan kation utama dan terlibat lansung dalam mempertahankan konsentrasi dan 
volume cairan ekstrasel, sangat menentukan osmolalitas cairan ektrasel. Natrium juga memiliki peran dalam melakukan penghantaran ransang dan kepekaan jaringan saraf dan otot, mempertahankan asam dan basa, mengatur masuk maupun keluar air dari vaskular, Nilai normal natrium plasma adalah 135$145 \mathrm{mEq} / \mathrm{L}$. Kelainan akibat kadar natrium plasma kurang dari $135 \mathrm{mEq} / \mathrm{L}$ disebut hiponatremia. Gejala hiponatremia dapat berupa mual, muntah, gelisah, kebingungan, hipotensi, bradikardi, kejang, dan respiratory arrest. ${ }^{10,12,14}$ Kelainan akibat kadar natrium plasma lebih dari $145 \mathrm{mEq} / \mathrm{L}$ disebut hipernatremia. Gejala hipernatremia dapat berupa letargi, iritabel, kejang, dan koma. ${ }^{8}$

Suatu studi memperlihatkan penurunan natrium dari setiap operasi TURP yang dibagi menjadi 45-55 menit, 55-65 menit dan 65-85 menit adalah sebanyak 1,27\%, 3,4\% dan 7,5 \%. ${ }^{15}$ Penelitian lain juga memperlihatkan penurunan natrium pada lama operasi TURP kurang dari 1 jam sebanyak 3,763 mMol/L dan pada lama operasi TURP lebih dari 1 jam sebanyak 6,692 mMol/L. ${ }^{6}$ Studi yang lain menunjukkan adanya korelasi penurunan serum natrium dan peningkatan kalium setelah operasi TURP yang berhubungan lansung dengan banyak cairan irigasi yang dipakai, lama operasi, dan volume prostat yang direseksi. ${ }^{16}$

\section{METODE}

Penelitian ini merupakan studi analitik observasional dengan rancangan potong lintang. Penelitian dilakukan dengan mengambil data rekam medik di bagian Rekam Medik RSUP Dr. M. Djamil Padang, dengan rentang waktu penelitian dari bulan Maret 2018 sampai dengan Juli 2018.

Populasi penelitian ini adalah semua pasien yang telah didiagnosis BPH oleh dokter bedah urologi dan mendapatkan terapi TURP di bagian Bedah RSUP Dr. M. Djamil Padang.

Sampel penelitian yang dipilih adalah pasien $\mathrm{BPH}$ yang melakukan TURP yang memenuhi kriteria inklusi dan eksklusi. Kriteria inklusi subjek: pasien yang terdiagnosis $\mathrm{BPH}$ dan telah dilakukan TURP dengan pemeriksaan kadar natrium sebelum dan sesudah operasi. Kriteria eksklusi subjek: pasien yang terdiagnosis $\mathrm{BPH}$ dengan gangguan ginjal dan pasien yang terdiagnosis BPH dengan kelainan jantung.

Data diperoleh dengan cara observasi rekam medik pasien yang didiagnosis BPH dan dilakukan TURP oleh dokter spesialis Urologi di bagian Bedah RSUP Dr. M. Djamil Padang.

Data dianalisis secara statistik berdasarkan variabel yang dinilai menggunakan sistem komputerisasi yaitu analisis univariat dan bivariat. Analisis univariat dilakukan untuk melihat distribusi masing-masing variabel dependen dan independen. Analisis bivariat dilakukan untuk menganalisis hubungan antara variabel independen dan variabel dependen. Teknik analisa data yang digunakan pada penelitian ini adalah uji korelasi Pearson

\section{HASIL}

Telah dilakukan penelitian secara retrospektif terhadap pasien BPH yang melakukan TURP di bagian Rekam Medis RSUP Dr. M. Djamil Padang. Dalam penelitian didapatkan 20 sampel yang memenuhi kriteria inklusi dan tidak memenuhi kriteria eksklusi. Terdapat total 67 pasien BPH yang melakukan TURP pada tahun 2016.

Hasil penelitian didapatkan rerata usia pasien $\mathrm{BPH}$ yang melakukan TURP adalah 67,15 $\pm 9,53$ tahun, dengan rentang usia 58 sampai dengan 89 tahun.

\section{Distribusi Frekuensi Responden menurut Lama Operasi TURP}

Tabel 1. Distribusi frekuensi responden menurut lama operasi TURP di RSUP Dr. M. Djamil Padang

\begin{tabular}{ccccc}
\hline & Rerata & $\begin{array}{c}\text { Standar } \\
\text { Deviasi }\end{array}$ & Min & Maks \\
\hline Lama & 63,25 & 18,59 & 30 & 90 \\
$\begin{array}{c}\text { Operasi } \\
\text { TUR-P }\end{array}$ & menit & & Menit & menit \\
\hline
\end{tabular}

Berdasarkan Tabel 1 dapat dilihat rerata lama operasi TURP adalah 63,25 menit dengan nilai standar deviasi sebesar 18,59. Operasi paling cepat dilakukan dalam waktu 30 menit dan operasi paling lama dilakukan dalam waktu 90 menit. 
Distribusi Frekuensi Responden menurut Perubahan Kadar Natrium pasca Operasi TURP

Tabel 2. Distribusi frekuensi responden menurut perubahan kadar natrium pasca operasi TURP di RSUP Dr. M. Djamil Padang

\begin{tabular}{ccccc}
\hline & Rerata & $\begin{array}{c}\text { Standar } \\
\text { Deviasi }\end{array}$ & Min & Maks \\
\hline $\begin{array}{c}\text { Perubahan } \\
\text { Kadar } \\
\text { Natrium }\end{array}$ & $\begin{array}{c}5,0 \\
\mathrm{mEq} / \mathrm{L}\end{array}$ & 3,4 & $\begin{array}{c}1 \\
\mathrm{mEq} / \mathrm{L}\end{array}$ & $\begin{array}{c}\mathrm{mEq} \\
\mathrm{L}\end{array}$ \\
\hline
\end{tabular}

Berdasarkan Tabel 2 dapat dilihat rerata lama perubahan kadar Natrium adalah $5,0 \mathrm{mEq} / \mathrm{L}$ dengan nilai standar deviasi sebesar 3,4. Perubahan kadar Natrium tertinggi yaitu $13 \mathrm{mEq} / \mathrm{L}$ dan perubahan kadar Natrium terendah yaitu $1 \mathrm{mEq} / \mathrm{L}$. Hasil observasi didapatkan terjadi perubahan kadar Natrium sesudah operasi TURP, dalam hal ini berupa penurunan kadar Natrium. Seluruh sampel penelitian mengalami penurunan kadar Natrium sesudah operasi.

\section{Korelasi Lama Operasi dengan Perubahan Kadar Natrium pasca Operasi TURP}

Tabel 3. Korelasi lama operasi dengan perubahan kadar natrium pasca operasi TURP

\begin{tabular}{ccc}
\hline & \multicolumn{2}{c}{ Perubahan Kadar Natrium } \\
\cline { 2 - 3 } & $\mathbf{r}^{*}$ & $\mathbf{p}^{*}$ \\
\hline Lama Operasi & 0,141 & 0,552 \\
\hline${ }^{*}$ Pearson Correlation Test & &
\end{tabular}

Berdasarkan Tabel 3, didapatkan bahwa nilai $p>0.05(p=0,552)$ artinya terdapat hubungan yang tidak bermakna antara lama operasi TURP dengan perubahan kadar Natrium dengan korelasi sangat lemah $(r=0,141)$ dan arah korelasi positif, yang artinya semakin lama operasi TURP maka semakin besar perubahan kadar Natrium. Dalam hal ini, perubahan yang terjadi adalah penurunan kadar Natrium.

\section{PEMBAHASAN}

Transurethral Resection of the Prostate merupakan prosedur baku untuk terapi bedah $\mathrm{BPH}^{3,6}$ TURP dapat menyebabkan perubahan kadar Natrium karena adanya cairan irigasi yang masuk ke dalam sirkulasi melalui vena yang tereseksi selama operasi. ${ }^{17}$ Kelebihan cairan yang masuk kedalam sirkulasi dapat menyebabkan kondisi hiponatremia yang dapat menjadi sindroma TURP. ${ }^{18,19}$ Sindroma TURP rentan terjadi jika operasi dilakukan dalam waktu lebih dari 60 menit. $^{12}$

Penelitian ini telah dilakukan terhadap 20 sampel Rekam Medis pasien BPH yang mendapatkan terapi TURP di RSUP Dr. M. Djamil Padang, dengan menggunakan aquades dalam prosedurnya. Didapatkan rata-rata usia pasien $\mathrm{BPH}$ yang melakukan TURP adalah 67,15 tahun. Usia terkecil yang melakukan operasi TURP adalah 50 tahun sedangkan usia terbesar yang melakukan operasi TURP adalah 89 tahun. Hal ini sesuai dengan teori BPH adalah penyakit degeneratif yang mana insidensinya meningkat seiring dengan pertambahan usia dan umumnya terjadi pada pria berusia diatas 40 tahun. $^{4}$ Suatu penelitian mendapatkan rata-rata usia subyek penelitian yang mendapatkan terapi TURP adalah 66,8 tahun dengan rentang usia 54 sampai dengan 84 tahun. $^{13}$

Didapatkan rerata lama operasi TURP adalah 63,25 menit dalam penelitian ini (Tabel 1). Lama operasi TURP yang dilakukan di RSUP Dr. M. Djamil termasuk dalam waktu resiko rendah untuk terjadinya sindroma TURP karena masih berada dalam waktu rekomendasi operasi selama 60 menit. $^{12}$ Penelitian terdahulu memperlihatkan hasil rerata lama operasi yang juga hampir sama yaitu 60,80 \pm 8,62 menit untuk operasi lebih 30 menit. Penelitian Patel dan Patel terhadap 50 pasien JJ Hospital Mumbai, yang terbagi dalam 2 kelompok: 25 subyek untuk lama operasi kurang dari 30 menit dan 25 subyek untuk lama operasi lebih dari 30 menit. $^{20}$

Perubahan kadar Natrium yang didapatkan pada penelitian ini adalah $5,0 \mathrm{mEq} / \mathrm{L}$ (Tabel 2). Dari hasil observasi didapatkan terjadi perubahan kadar natrium sesudah operasi TURP berupa penurunan kadar Natrium dan seluruh sampel penelitian mengalami penurunan kadar natrium sesudah operasi. Perubahan kadar natrium sesudah operasi TURP disebabkan oleh cairan irigasi yang masuk ke dalam sirkulasi melalui vena yang tereseksi selama operasi TURP. $^{17}$ Terlalu banyak cairan menyebabkan kelebihan cairan di dalam sirkulasi yang dapat menimbulkan kondisi hiponatremia sehingga sindroma TURP dapat terjadi. ${ }^{18,19}$ 
Didapatkan korelasi positif sangat lemah antara lama operasi dengan perubahan kadar Natrium pasca operasi TURP di RSUP Dr. M. Djamil Padang. Penelitian ini juga menunjukkan hubungan yang tidak bermakna secara statistik antara lama operasi dengan perubahan kadar Natrium pasca operasi TURP di RSUP Dr. M. Djamil Padang (Tabel 3).

Hasil korelasi positif sangat lemah dengan hubungan yang tidak bermakna disebabkan oleh lama operasi TURP di RSUP Dr. M Djamil masih berada dalam rentang waktu aman melakukan operasi sekitar 60 menit karena operasi lebih dari rentang waktu tersebut dapat menyebabkan resiko terjadinya sindroma TURP. ${ }^{12}$ Pada penelitian ini juga mendapatkan tidak satupun sampel yang mengalami hiponatremia akut yang berujung pada sindroma TURP.

Korelasi lama operasi dan perubahan kadar Natrium sesudah TURP juga mendapatkan hasil tidak signifikan bermakna secara statistik pada penelitian $(r=0,122, p=0,480) .{ }^{21}$ Didapatkan hasil peneltian yang sama dan didapatkan kasus hiponatremia akibat cairan irigasi yang diserap jarang terjadi sehingga memberikan kesimpulan bahwa air steril adalah cairan irigasi yang aman dan ekonomis untuk TURP. ${ }^{13}$

\section{SIMPULAN}

Terdapat korelasi positif sangat lemah dengan hubungan yang tidak bermakna antara lama operasi dengan perubahan kadar Natrium pasca operasi TURP di RSUP Dr. M. Djamil Padang.

\section{DAFTAR PUSTAKA}

1. Mochtar CA, Umbas R, Soebadi DM, Rasyid N, Noegroho BS, Poernomo BB, et al. Panduan penatalaksanaan klinis pembesaran prostat jinak (benign prostatic hyperplasia/BPH). Edisi ke-2. Ikatan Ahli Urologi Indonesia; 2015.

2. McNicholas T, Mitchell S. Benign Prostatic Hyperplasia. Medical Progress. 2009;36(4):178-83.

3. Gaol HL, Mochtar CA. Hiperplasia prostat jinak. Dalam: Tanto C, Liwang F, Hanifati S, Pradipta, EA, editor (penyunting). Kapita Selekta Kedokteran. Edisi ke-4 jilid 1. Jakarta:FK-UI; 2016. hlm.284-7.
4. Wu Y, Davidian MH, DeSimone EM, Guidelines for the treatment of benign prostatic hyperplasia. US Pharmacist. 2016;41(8):36-41.

5. Parsons JK. Benign prostatic hyperplasia and male lower urinary tract symptoms: epidemiology and risk factors. Curr Bladder Dysfunct Rep. 2010;5:212-8.

6. Khomeini, Efmansyah D, Erkadius. Hubungan penurunan kadar natrium terhadap gangguan pola tidur pasca TURP (transurethral resection of the prostate). Jurnal Kesehatan Andalas. 2013;2(1):913.

7. Etriyel. Hubungan ekspresi transforming growth factor B1, matrix metalloproteinase-1, tissue inhibitor matrix metalloproteinase-3 dengan kepadatan fibrosis pasca transurethral resection of prostate (disertasi). Padang: Prodi S3 Biomedis FK Universitas Andalas; 2017.

8. Umbas R. Saluran kemih dan alat kelamin lelaki. Dalam: Sjamsuhidajat $R$, Karnadihardja W, Prasetyono TOH, Rudiman R, editor (penyunting). Buku ajar ilmu bedah Sjamsuhidajat-de Jong. Edisi ke-3. Jakarta: Penerbit Buku Kedokteran EGC; 2010.hlm. 899-902.

9. Purnomo BB. Dasar-dasar urologi. Malang: FKUniversitas Brawijaya; 2008.hlm.69-81.

10. Collins MA. Transurethral Resection of the Prostate [Internet]. Medscape. 2017 (diakses13 Oktober 2017). Tersedia dari: https://emedicine.medscape. com/article/449781-overview

11. Moorthy HK, Philip S. TURP syndrome current concepts in the pathophysiology and management. Indian Journal of Urology. 2001;17(2):97-102.

12. Hawary A, Muchtar K, Sinclair A, Pearce I. Transurethral resection of the prostate syndrome: almost gone but not forgotten. Journal of Endourology. 2009;23(12):2013-20.

13. Moharari RS, Khajavi MR, Khamdemhosseini $P$, Hoesseini SR, Najafi A. Sterile water as an irrigating fluid for transurethral resection of the prostate: anesthetical view of the record of 1600 cases. Sonten Medical Journal. 2008;101(4):373-5.

14. Mir F. Serum sodium. Medscape. 2013 (diakses 9 November 2017). Tersedia dari: https://emedicine. medscape.com/2099065-overview 
15. Gupta K, Rastogi B, Jein M, Gupta PK, Sharma D. Electrolyte changes: An indirect method to assess irrigation fluid absorption complications during transurethral resection of prostate: A prospective study. Saudi Journal of Anaesthesia. 2010;4(3):142-6.

16. Petrusheva AP, Kuzmanosvska B, Mojsova M, Kartalov A, Spirovska T, Shosholcheva M, et al. Evaluation of changes in serum consentration of sodium in a transurethral resection of the prostate. Prilozi. 2015;36:117-27.

17. Kurniawan W. Comparison of serum sodium, serum potassium, and blood hemoglobin changes after transurethral resection of the prostate between irrigation with normal saline and sterile water. JURI. 2011;18(2):55-9.

18. Pasha MT, Khan MA, Jamal Y, Wahab F, Ashraf $H$,
Naemullah. Postoperative complications glycine and sterile distilled water after transurethral resection of the prostate. J Ayub Med Coll Abbottabad. 2015;27(1):135-9.

19. Dissayabutra T, Ungjaroenwathana W, Bunyaratavej C, Prasopsanti K, Tosukhowong P. Irrigation with water during transurethral resection of the prostate (TURP) induces intravascular hemolysis. Asian Medicine. 2013;7(6):795-802.

20. Patel SN, Patel ND. Serum sodium and serum potassium changes during transurethral resection of the prostate gland in patients under subarachnoid block. National Journal of Medical Research. 2014;4(4):322-5.

21. Moorthy K, Philip S. Serum electrolytes in TURP Syndrome - is the role of potassium underestimated? Indian J. 2002;46(6):441-4. 